\title{
The Impact of Future Economic Stability and Family Influence on Students' Motivation for Higher Education: A Study on IIUM Students
}

\author{
Abdulhameed Kamoludeen Olasunkanmi \\ Kulliyyah of Education, \\ International Islamic University Malaysia, \\ Kuala Lumpur, Malaysia \\ alkalam07@gmail.com
}

\author{
*Madihah Khalid \\ Kulliyyah of Education, \\ International Islamic University Malaysia, \\ Kuala Lumpur, Malaysia \\ madihahkhalid@iium.edu.my
}

\begin{abstract}
This study was conducted to investigate the relationship between future economic stability (FES), family influence (FI) and students' motivation for higher education (MFHE) based on the perceptions of undergraduate students in IIUM. The questionnaire used was self-developed and piloted with 263 undergraduate students, who were sampled purposely. Content validity, construct validity and - the Cronbach's alpha for reliability were conducted to validate the instrument. SPSS V25 was used to analyze the data by manipulating the descriptive and inferential statistics. The findings from data analysis indicated that IIUM students held positive perception towards FES, FI and MFHE. The results also revealed a positive and significant relationship between FES, FI and MFHE, and that FES and FI were found to be significant predictors of MFHE. As an implication, higher education institutions as well as parents are urged to support their wards in terms of employment opportunities and continuous parental support, as the impact of future economic stability and family influence have been confirmed in this study as part of the reasons behind students' motivation for higher education learning.
\end{abstract}

Keywords: Future economic stability, family influence, students' motivation, higher education, undergraduate students

\section{INTRODUCTION}

Education is the foundation of human development and growth that emphasizes cognitive, affective, and psychomotor domains of learning. It is a process through which economic, social, political, and moral lives could be expanded, improved, and rebranded. To support this claim, Grant (Grant, 2017) postulates that education is a pioneer determinant of economic growth, employment and earnings. Similarly, Heckman (2011) also concurs that education is a system that has effect on the labour strength quality and capacity of transformation in deciding the potentiality of a nation's development. 
In the process of gaining a significant place among the educational hubs at the global level, Malaysian government, every year, allocates the highest budget for the education sector, reflecting its serious commitment to this aim. This places Malaysian educational system almost at the same level with other developed countries. Maintaining higher educational growth and expansion in Malaysia requires students' motivation towards the enrolment and retention until the graduation period, and this is a concern of the government and other education stakeholders. Motivation for higher education (MFHE) in the context of this study refers to intrinsic motivation of International Islamic University Malaysia (IIUM) students towards higher education. In other words, MFHE indicates the internal willingness of IIUM students towards attaining higher education.

Pursuing higher education has been observed as a critical period for students' well-being and their learning outcome (Edgar et al., 2019). Recent literature indicated that students' motivation has not been accorded necessary attention though it is seen as a catalyst for students' accomplishment and retention (Edgar et al., 2019). Fajčíková and Urbancová (2019) confirmed that future economic stability is one of the factors that contributes to students' quest for higher education. This indirectly indicates that highly-rated job and reasonable salary seem to be an influencer for students' pursuit of higher education (Huang \& Ho, 2017). To support future economic stability (FES) as one of the variables of the study, Abraham Maslow in his hierarchy of needs proposed that human beings by nature are eligible to physiological and safety needs, which are levels 1 and 2 of human needs. These needs include food, shelter, security, stability, dependency and freedom from fear. Thus, FES would represent level 1 and level 2 of Maslow's theory, which are physiological and safety needs. Literatures also indicated that parental expectation and educational aspiration (family influence) is another factor that has a great influence on students' motivation for higher education (Li \& Qiu, 2018). Family influence could be embedded into subjective norm which indicated a perception someone holds to some significant people around him concerning performing or not performing a behavior. In the context of this study, subjective norm in the form of family influence is the impact of parents, siblings and extended family members on IIUM students for them to be motivated towards higher education.

To produce holistic entrepreneurial and balanced graduates as part of the aims and objectives of the Malaysian Higher Education Blueprint (2015-2025), students need to be motivated and encouraged on the significance of achieving higher educational degrees coupled with the nation's sustainable growth which has been embedded in Malaysian Shared Prosperity Vision 2030. Hence, the current study aims to:

1. explore the level of IIUM students' perception on future economic stability, family influence and motivation for higher education.

2. determine the relationship between future economic stability and IIUM students' motivation for higher education.

3. establish the relationship between family influence and IIUM students' motivation for higher education.

4. investigate whether future economic stability and family influence predict IIUM students' motivation for higher education. 


\section{LITERATURE REVIEW}

\section{Maslow's Hierarchy of Needs}

Abraham Maslow was one of the scholars who came up with Motivation Theory in 1953. His work on motivation was recognized as Maslow's hierarchy of needs. He proposed this theory on a view that human beings are inspired by 5 types of universal needs, and ranked the needs based on their influence on human behaviour. At the bottom of this hierarchy is the physiological needs which enables human beings to exist in life. Physiological needs include food and drink. Second in the hierarchy is the safety needs which include shelter, stability, security and freedom from fear and anxiety (Schunk, 2012). Social needs according to Maslow, entails belongingness and love that allow people to interact and collaborate with one another. The fourth in hierarchy is the ego and esteem needs which would enable human beings to consider themselves as real human beings. These needs entail self-respect, self-esteem, desire for reputation, status and prestige. At the top of the hierarchy is the self-actualization that would make an individual attain his self-realization and self-development, and pursue what is achievable in life. However, physiological and safety needs of Maslow represent future economic stability as one of the variables of this study.

\section{Subjective Norm}

Subjective norm can be referred to as the perceived social pressure or influence that summons someone's attitude to embark or not to embark on a particular behaviour (Ajzen, 1991; O'Neal, 2007). According to Al-Swidi et al. (2014) and Hasbullah et al. (2016), subjective norm refers to individuals' judgement regarding how they would be perceived by their group upon a particular behaviour. Hence, individuals' group might involve parents, neighbors, peers, friends and other immediate and non-immediate family members. With respect to this study, subjective norm in the form of family influence indicates the impact of parents, siblings, and other extended family members on students for them to be attracted towards higher education.

\section{Intrinsic Motivation}

Intrinsic motivation can be defined as the internal effort to carry out a certain activity for its natural pleasure and not for some material gains (White, 1959). Similarly, Richard and Deci (1985) operationally defined intrinsically motivated behaviour as someone's engagement in an activity without any external reward or influence. These meanings of intrinsic motivation indicate that when students are self-influenced to attain knowledge or people are self-moved to embark on some activities without being attracted by any extrinsic forces, they are intrinsically motivated to pursue their tasks. Although Ryan et al. (2005) believe that intrinsic motivation is not the only way of getting human beings motivated, it is the predominant and essential one. Considering the context of this study, motivation for higher education (MFHE) as the dependent variable is an intrinsic motivation that sparks students' interest towards acquiring higher education. 


\section{Future Economic Stability and Motivation for Higher Education}

Future economic stability (FES) in the context of this study refers to students' future financial security that prompts their motivation towards higher education. Higher education in the last few decades, has been aimed to boost national growth, rejuvenate economic routes, and pave the way forward in withstanding the present challenges of the world (Harvey, 2000). This led policy makers and researchers to focus their attention to the relationship between higher education and employment (Pagés \& Stampini, 2009). Meeting up with the global challenges has made many higher institutions to groom their students for the global market without underestimating the objective of education (Warrick et al., 2010). Part of the objectives of attending higher education is to nurture students for opportunities, careers, suitable employment and preparation for the real life (Pagés \& Stampini, 2009).

Several findings revealed that high job stability and reasonable salary are the vital reasons for students to enrol for various higher education degrees (Huang \& Ho, 2017). This shows that future economic stability is something important to university students upon their graduation. Equally, finding also indicated that global market requires competent and highly qualified graduates who have received skills and trainings needed for emerging global marketplace (Ali \& Jalal, 2018). This indicates the strong connection between higher education and the world of employment. Students from diverse background consider higher education as the only guarantor for a secured livelihood regardless the cost of participation (Wright \& Horta, 2018). It would be interesting enough to examine whether future economic stability could also determine IIUM students' motivation for higher education as it has been established in the literature.

\section{Family Influence and Motivation for Higher Education}

Family influence in the case of this study, refers to the impact of parents, siblings, and extended family members on students for them to be motivated for higher education. However, families are considered a vital context that shapes teenagers' educational prospect through parental anticipation and parental support for higher education enrolment (Bronfenbrenner, 1979; Byun et al., 2017; Byun et al., 2012, 2015; Fuligni \& Pedersen, 2002; Parsons et al., 1983). Considering this, Agger et al. (2018) suggested that perceived parental expectations have a huge effect on post-secondary educational aspirations. The finding indicated that an increased in enrolling for postsecondary institution is linked with the parental expectations and educational aspiration.

Furthermore, previous finding indicated that adolescents' higher educational success is strongly attached to parental expectation and involvement (Benner et al., 2016). This establishes that family has a great influence on students' motivation for higher education pursuit. Literature further revealed that family expectation and involvement could be the source of encoragement and motivation for children's quest for futher study (Li \& Qiu, 2018). This is to say that the higer the parental expectation and involvement, the better the academic accomplishment of the 
children (Li \& Qiu, 2018). In the same vein, Gobena (2018) found that educated families always influence their children's educational adventure through necessary guidance and counseling. It is aimed in this study as well to investigate whether family influence predicts IIUM students' motivation for higher education enrolment and accomplishment.

\section{The Present Study}

This study investigates IIUM undergraduate students' perception with respect to future economic stability (FES) and family influence (FI) and the relationship between FES, FI and students' motivation for higher education. This investigation would be interesting as a result of the previous empirical links between FES and students' motivation for higher education as well as FI and students' quest for higher education. As mentioned in the literature review, FES and FI are able to predict students' motivation for higher education. The present study also intends to examine whether this prediction exists as well in the context of IIUM students.

The combined prediction of FES and FI of MFHE has not been found in the previous studies. Thus, this present study proposes to investigate whether this model could generate new finding and contribute new framework to the body of knowledge. Although the model is being proposed in the context of IIUM students, future studies could as well test the framework on the larger community and society.

\section{Figure 1}

\section{Conceptual Framework}

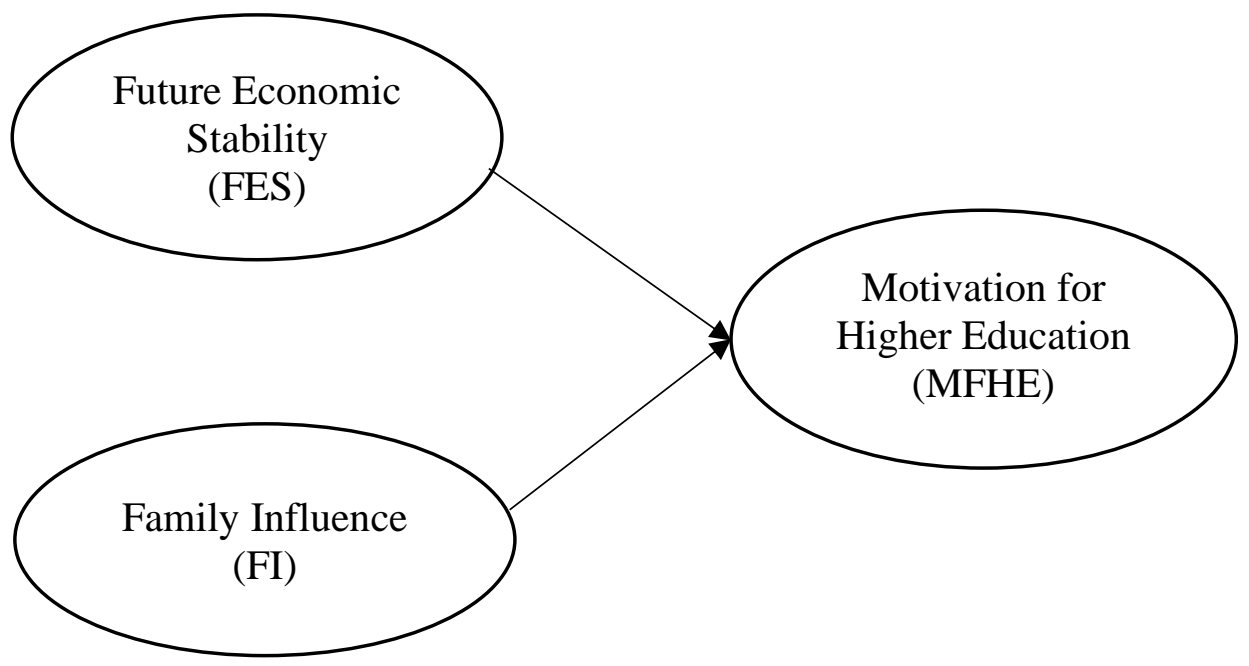

This research proposed the following hypotheses:

H1: There is a relationship between future economic stability and IIUM students' motivation for higher education.

$H 2$ :There is a relationship between family influence and IIUM students' motivation for higher education.

H3: Future economic stability can predict IIUM students' motivation for higher education.

H4: Family influence can predict IIUM students' motivation for higher education. 


\section{METHODODLOGY}

\section{Research Design}

The study adopted the correlational quantitative research design to answer the research questions. It was based on a pilot study involving 263 undergraduate students from International Islamic University Malaysia (IIUM) who were purposely surveyed via questionnaire. The quantitative data were analysed using SPSS version 25. Additionally, inferential statistics was employed to guide the researchers to test the hypotheses of the study through examining the Pearson correlation and regression results. It assisted in producing the necessary descriptive results, like the means and standard deviations of the factors and items.

\section{The Development of the Survey Questionnaire}

The survey questionnaire used in the study was developed and validated to suit the context of the study. The questionnaire contained two independent variables of future economic stability (10 items) and family influence (10 items) and a dependent variable of motivation for higher education (10 items). A seven-point Likert scale was utilised where each item was responded to with the selection of $1=$ Strongly Unimportant, $2=$ Unimportant, $3=$ Somewhat Unimportant, 4=Neutral, 5=Somewhat Important, 6=Important and 7=Strongly Important. The items of the questionnaire are shown in Table 3 . This questionnaire was piloted and reported in Table 1.

\section{Validation of the Survey Questionnaire}

Five experts were consulted for the content validity of the instrument, and the validated version of the instrument was rated on the level of item statement between clarity and ambiguity using interrater method through the discussion of the experts as suggested by (Swerdlik \& Cohen, 2005). Factor analyses were employed to determine the reliability, internal consistency, and factorial validity of the items in each variable of the survey. The factor loading is as shown in Table 1. The variables measured in the survey were future economic stability (FES), Family influence (FI) and motivation for higher education (MFHE). 


\section{Table 1}

Factor Structure, Factor Loadings, Eigenvalue, Variance Explained and Internal Consistency Index

\begin{tabular}{|c|c|c|c|c|}
\hline Factors and Indicators & $\begin{array}{c}\text { Factor } \\
\text { Loading }\end{array}$ & $\begin{array}{l}\text { Eigen- } \\
\text { value }\end{array}$ & $\begin{array}{l}\text { Variance } \\
\text { Explained }\end{array}$ & $\begin{array}{l}\text { Reliability } \\
\text { Index }\end{array}$ \\
\hline Factor 1: Motivation for Higher & & 16.73 & 60.99 & 96 \\
\hline \multicolumn{5}{|l|}{ Education } \\
\hline Motivation 9 & .916 & & & \\
\hline Motivation 8 & .890 & & & \\
\hline Motivation 6 & .866 & & & \\
\hline Motivation 4 & .861 & & & \\
\hline Motivation 7 & .827 & & & \\
\hline Motivation 5 & .827 & & & \\
\hline Motivation 1 & .765 & & & \\
\hline Motivation 2 & .745 & & & \\
\hline Motivation 3 & .738 & & & \\
\hline Motivation 10 & .735 & & & \\
\hline Factor 2: Future Economic Stability & & 1.903 & 6.027 & .95 \\
\hline FES 7 & .901 & & & \\
\hline FES 5 & .888 & & & \\
\hline FES 3 & .878 & & & \\
\hline FES 6 & .817 & & & \\
\hline FES 8 & .800 & & & \\
\hline FES 10 & .746 & & & \\
\hline FES 2 & .733 & & & \\
\hline FES 1 & .714 & & & \\
\hline FES 4 & .669 & & & \\
\hline FES 9 & .577 & & & \\
\hline Factor 3: Family Influence & & 1.590 & 4.848 & .93 \\
\hline Family 9 & .950 & & & \\
\hline Family 8 & .887 & & & \\
\hline Family 7 & .848 & & & \\
\hline Family 6 & .841 & & & \\
\hline Family 5 & .708 & & & \\
\hline Family 4 & .571 & & & \\
\hline Family 10 & .569 & & & \\
\hline
\end{tabular}

Note.

Extraction Method: Principal Axis Factoring

Rotation Method: Promax with Kaiser Normalization

The Promax rotation extracted a clean three-factor structure without any cross-loading or nonmeaningful loading. The solution was represented by twenty-seven (27) items from the original 30 and explained approximately $71.8 \%$ of the variance in the data. The three-factor structure of the variables is presented in Table 1 together with the factor loadings, variance explained, eigenvalues and internal consistency indexes of the variables. However, the KMO value was .96 and is considered creditable (Field, 2013), indicating that the sample size after the exclusion of the outliers was enough for running PAF. The Bartlett's test was statistically significant $\left(\chi^{2}\right.$ $=7879.28,351, \mathrm{p}=0.000)$. There was no issue of multicollinearity as all the items were moderately correlated with value falling below 0.8 . 
All the 10 items under the motivation for higher education factor loaded into factor 1. The factor loadings for the items were somewhat high, with value ranging between .735 and 916. Hence "motivation for higher education", as hypothesized, was maintained as the label for factor 1. It explained about $60.9 \%$ of the variance. Factor 2 explained $6.0 \%$ of the variance and was represented as well by ten of the proposed future economic stability items with factor loadings ranging from .577 to .901 . The remaining seven loaded on the proposed family influence items with factor loadings ranging between .569 and .950 and explained $4.8 \%$ of the variance. However, literatures recommend that any item with loading of 0.05 could be retained (Ladhari, 2010; Wolfinbarger \& Gilly, 2003).

Table 1 also shows the reliability indices derived from the survey questionnaire for the three different variables of FES, FI and MFHE. Since the Cronbach alpha reliability ranged from 0.93 to 0.96 , then this implies that the scales are satisfactory in terms of internal consistency.

From all of the result above, it can then be established that the instrument is valid and reliable for the use of data collection.

\section{FINDINGS AND ANALYSIS}

\section{Demographic Information}

The demographic information from 263 IIUM students who completed the survey is indicated in Table 2.

\section{Table 2}

Demographics of Respondents

\begin{tabular}{lllllllll}
\hline \multicolumn{2}{c}{ Gender of Students } & \multicolumn{3}{c}{ Ethnicity of Students } & \multicolumn{3}{c}{ Students' year of Study } \\
\hline Gender & Frequency & Percent & Ethnicity & Frequency & Percent & Year & Frequency & Percent \\
Male & 89 & 33.8 & Malay & 254 & 96.6 & Year1 & 58 & 22.1 \\
Female & 174 & 66.2 & Chinese & 2 & 0.8 & Year2 & 44 & 16.7 \\
\hline Total & 263 & 100.0 & Others & 7 & 2.7 & Year3 & 107 & 40.7 \\
& & & Total & 263 & 100.0 & Year4 & 54 & 20.6 \\
\cline { 4 - 8 } & & & & & Total & 263 & 100.0 \\
\cline { 4 - 7 }
\end{tabular}

The participants who responded to the survey questionnaire were pursuing undergraduate programmes from different kulliyyahs (faculties) between the year 2019 and 2020. Year 1 $(n=58)$, year $2(n=44)$, year $3(n=107)$ and year 4 and above $(n=54)$. Table 2 indicates that majority of the students were Malays $(n=254,96.6 \%)$ followed by students from other ethnicities $(n=7,2.7 \%)$ while Chinese students were only $(n=2,0.8 \%)$. Regarding gender, $66.2 \%(n=174)$ of the respondents were females and $33.8 \%(n=89)$ of them were males because of a high population of female students studying in IIUM. The demographic also indicates that Malaysians were the majority students in IIUM. In terms of level of study, year three students were the top respondents $(n=107,40.7 \%)$ followed by year one $(n=58,22.1 \%)$, year four students came third in the response hierarchy $(n=544,20.6 \%)$ while year two students were the lowest respondents $(n=44,16.7 \%)$. 


\section{Students' Perception of Future Economic Stability, Family Influence and Motivation for Higher Education}

Descriptive analysis was run to check the level of IIUM students' perception towards future economic stability (FES), family influence (FI) and motivation for higher education (MFHE). As indicated in Table 3 below, Future economic stability (independent variable 1) has a mean score of 5.82 (on a 7-point scale). Family influence (independent variable 2) has a mean score of 5.60, while motivation for higher education (dependent variable) has a mean score of 5.90. These mean scores generally signify that IIUM students perceived future economic stability, family influence and motivation for higher education as important since the means are closer to 6.

\section{Table 3}

Results of Descriptive Statistics of Items' Mean and SD (DV: Motivation for Higher Education)

\begin{tabular}{llcc}
\hline No & \multicolumn{1}{c}{ Items } & Mean & SD \\
\hline & Future Economic Stability & 5.82 & 1.34 \\
1 & The desire to afford house utility & 6.01 & 1.44 \\
2 & The desire to afford comfortable healthcare in life & 6.04 & 1.29 \\
3 & A future ability to afford a comfortable life & 5.77 & 1.37 \\
4 & The need to afford suitable housing & 5.18 & 1.58 \\
5 & A future financial stability & 5.82 & 1.31 \\
6 & The desire to afford a befitting transportation & 5.67 & 1.31 \\
7 & The desire to earn an attractive income & 5.88 & 1.25 \\
8 & The desire to acquire needed assets in life & 6.10 & 1.26 \\
9 & The desire to help less privileged people financially & 5.91 & 1.30 \\
10 & The need to afford going for holidays & 5.87 & 1.34 \\
\hline & Family Influence & 5.60 & 1.52 \\
11 & To realise my family's emphasis on education & 5.78 & 1.38 \\
12 & To be on par with most members of my family in terms of education & 5.07 & 1.73 \\
13 & To realize the value my family places on education & 5.63 & 1.54 \\
14 & To earn the respect of my family & 5.89 & 1.43 \\
15 & To set a good example for my siblings & 5.68 & 1.53 \\
16 & To please my family for being involved in my education & 5.61 & 1.53 \\
17 & To fulfil my parents' aspiration & 5.55 & 1.52 \\
\hline & Motivation for Higher Education & 5.90 & 1.37 \\
18 & To enhance my skills and talents for future success & 6.03 & 1.38 \\
19 & To acquire skills needed in life through higher education & 6.02 & 1.36 \\
20 & To fulfil my belief in lifelong learning & 5.86 & 1.40 \\
21 & To be in the environment that is suitable for intellectual explorations & 5.91 & 1.31 \\
22 & To increase my knowledge & 5.97 & 1.42 \\
23 & To satisfy my dream of being in a stimulating environment & 5.87 & 1.32 \\
24 & To interact with the notable professors/lecturers & 5.94 & 1.31 \\
25 & To be in the right place of study & 5.69 & 1.40 \\
26 & To be in the fascinating place to learn & 5.78 & 1.43 \\
27 & To be on a good platform to interact with the appropriate friends & 5.97 & 1.39 \\
\hline & & & \\
\hline
\end{tabular}




\section{Relationship between Future Economic Stability and Motivation for Higher Education}

Pearson correlation was used to determine the relationship between future economic stability and motivation for higher education. The correlation matrix in Table 4 indicates that future economic stability was significantly and positively correlated with IIUM students' motivation for higher education $(r=0.79, \mathrm{n}=263, \mathrm{p}<0.001)$.

\section{Table 4}

Correlation Matric between Future Economic Stability and Motivation for Higher Education

\begin{tabular}{llll}
\hline & mean FES & $\begin{array}{l}\text { Mean } \\
\text { MFHE }\end{array}$ \\
\hline & Correlation Coefficient & .000 & $.793^{* *}$ \\
\hline Sig. (2-tailed) &. & .000 \\
\hline $\mathbf{N}$ & 263 & 263 \\
\hline
\end{tabular}

Note. ${ }^{* *}$. Correlation is significant at the 0.01 level (2-tailed).

\section{Relationship between Family Influence and Motivation for Higher Education}

Pearson correlation was also run to investigate the relationship between family influence and motivation for higher education. The correlation matrix in Table 5 shows that family influence was significantly and positively related to IIUM students' motivation for higher education ( $\mathrm{r}=$ $0.69, \mathrm{n}=263, \mathrm{p}<0.001)$.

Table 5

Correlation Matric between Family Influence and Motivation for Higher Education

\begin{tabular}{lllll}
\hline & & \multicolumn{2}{c}{ mean FI $\begin{array}{l}\text { Mean } \\
\text { MFHE }\end{array}$} \\
\hline \multirow{3}{*}{ mean FI } & Correlation Coefficient & .000 & $.699^{* *}$ \\
\cline { 2 - 4 } & Sig.(2-tailed) &. & .000 \\
\cline { 2 - 4 } & $\mathbf{N}$ & 263 & 263 \\
\hline
\end{tabular}

Note. **. Correlation is significant at the 0.01 level (2-tailed).

Impact of Future Economic Stability and Family Influence on Students' Motivation for Higher Education

Regression analyses were employed to determine the impact of future economic stability and family influence on IIUM students' motivation for higher education. They were also adopted to determine whether future economic stability and family influence can predict IIUM students' motivation for higher education based on the perception of undergraduate students studying in IIUM. The data satisfy most of the eight assumptions required for multiple regression: the dependent and the two independent variables were measured on continuous scales, there are linear relationships between the dependent variable and independents variables (singly and 
collectively), homoscedasticity (fairly rectangular and concentrated around the center, as shown by the plot of residuals against the standardized predicted values in Figure 2), no multicollinearity and significant outliers, and the residuals are approximately normally distributed as confirmed from the P-P plot in Figure 3.

\section{Figure 2}

Scatterplot

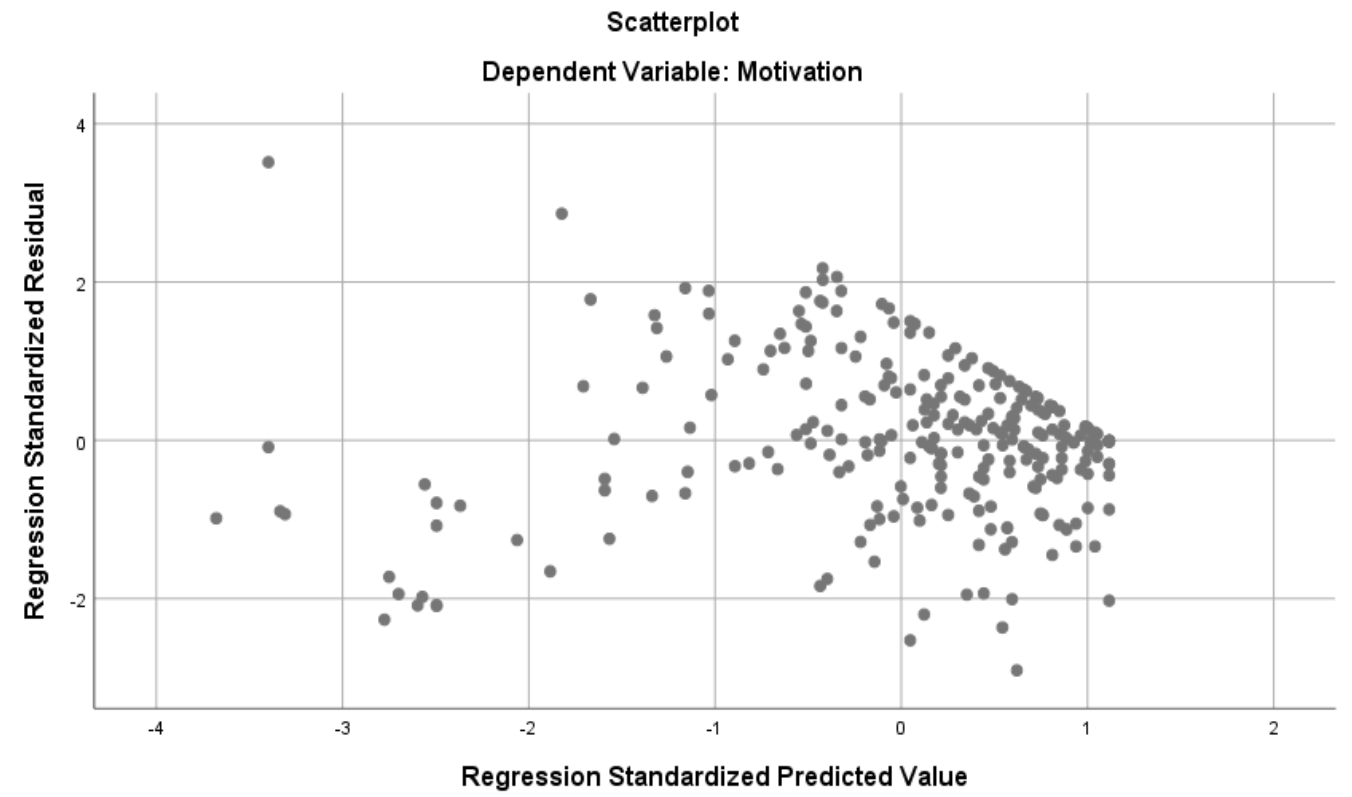

Figure 3

Normal P-P Plot of Regression

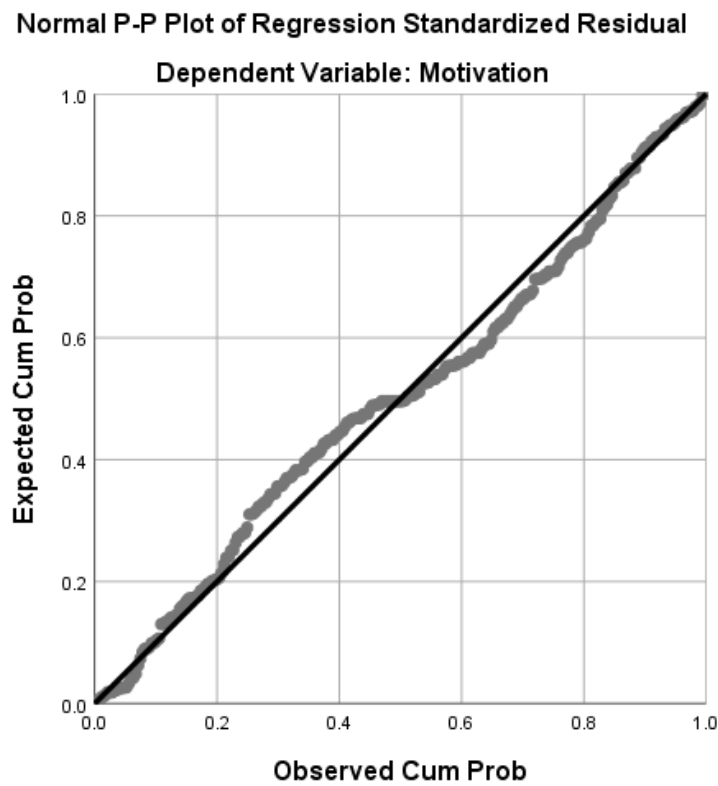


Table 6 of the multiple regression analysis indicates that $67.0 \%$ of the variance in IIUM students' motivation for higher education was explained by the model $\left(\mathrm{R}^{2}=0.67\right.$, $F(263)=263.72, p<0.001)$. Future economic stability was found to be better predictor of motivation for higher education $(\beta=0.62, p<0.001)$, followed by family influence $(\beta=0.18$, $\mathrm{p}<0.001)$.

Table 6

General Multiple Regression Analysis

\begin{tabular}{|c|c|c|c|c|c|c|}
\hline \multicolumn{7}{|c|}{ Coefficients $^{\mathbf{a}}$} \\
\hline & Model & & $\begin{array}{l}\text { nstandardized } \\
\text { Coefficients }\end{array}$ & $\begin{array}{c}\text { Standardized } \\
\text { Coefficients }\end{array}$ & $\mathbf{t}$ & Sig. \\
\hline \multirow{4}{*}{1} & & B & Std. Error & Beta & & \\
\hline & (Constant) & 0.07 & 0.02 & & 3.43 & .001 \\
\hline & FES & 0.62 & 0.052 & $0.59 * *$ & 11.93 & .000 \\
\hline & FI & 0.18 & 0.032 & $0.28 * *$ & 5.71 & .000 \\
\hline \multicolumn{7}{|c|}{ Model Summary } \\
\hline & & & $\mathrm{R}^{2}$ & Adjusted $\mathrm{R}^{2}$ & $\mathrm{~F}$ & $\mathrm{~N}$ \\
\hline 1 & & & 0.67 & 0.66 & $263.72 * *$ & 263 \\
\hline
\end{tabular}

Note. Dependent Variable: Motivation for Higher Education; **p $<0.001$

Finally, Table 7 shows all the hypotheses supported by the correlation and regression analyses. It indicates that all the hypotheses are significant.

Table 7

Hypotheses Presentation

\begin{tabular}{lll}
\hline \multicolumn{1}{c}{ Hypotheses } & \multicolumn{1}{c}{ Results } & Conclusion \\
\hline $\begin{array}{l}\text { H1: There is a relationship between future } \\
\text { economic stability and IIUM students' } \\
\text { motivation for higher education }\end{array}$ & $\begin{array}{l}\text { Yes: }(\mathrm{r}=0.79, \mathrm{p}<0.001) \\
\text { Significant }\end{array}$ & Supported \\
\hline $\begin{array}{l}\text { H2: There is a relationship between family } \\
\text { influence and IIUM students' motivation for } \\
\text { higher education. }\end{array}$ & $\begin{array}{l}\text { Yes: }(\mathrm{r}=0.69, \mathrm{p}<0.001) \\
\text { Significant }\end{array}$ & Supported \\
\hline $\begin{array}{l}\text { H3: Future economic stability can predict } \\
\begin{array}{l}\text { IIUM students' motivation for higher } \\
\text { education. }\end{array}\end{array}$ & $\begin{array}{l}\text { Yes. Significant } \\
\left(\mathrm{R}^{2}=0.67, \mathrm{p}<0.001\right) \\
(\beta=0.62, \mathrm{p}<0.001)\end{array}$ & Supported \\
\hline $\begin{array}{l}\text { H4: Family influence can predict IIUM } \\
\text { students' motivation for higher education. }\end{array}$ & $\begin{array}{l}\text { Yes. Significant } \\
\left(\mathrm{R}^{2}=0.67, \mathrm{p}<0.001\right. \\
(\beta=0.18, \mathrm{p}<0.001)\end{array}$ & Supported \\
\hline
\end{tabular}




\section{DISCUSSION}

The focus of this study was on the perception of IIUM students regarding future economic stability (FES), family influence (FI) and motivation for higher education (MFHE). It also investigated the relationship between FES, FI and MFHE. The study also examined whether FES and FI could be significant predictors of IIUM students' motivation for higher education.

Firstly, the descriptive results indicated that IIUM students perceived future economic stability, family influence and motivation for higher education as important elements in pursuing higher education. The finding also corresponds to the study of Huang and Ho (2017), Li and Qiu (2018) which stated that post-secondary students considered future financial stability (physiological and safety needs) and parental expectations (subjective norm) as paramount external factors/determinants of their passion (intrinsic motivation) towards higher education enrolment.

Secondly, the findings revealed that there is a positive significant relationship between future economic stability and IIUM students' motivation for higher education. This is consistent with the findings of Ali and Jalal (2018) which indicated a strong relationship between higher education attainment and the world of employment. Unarguably, attaining higher education leads to securing good employment and good employment seems to be a guarantee for future economic stability. The findings of this study also established a positive significant relationship between family influence and IIUM student motivation for higher education study. This also came in support of a study conducted by Benner et al. (2016).

Finally, the study found that future economic stability is a significant predictor of students' motivation for higher education. This finding concurs with the findings of Fajčíková and Urbancová (2019), Wright and Horta (2018) and Huang and Ho (2017) who previously established the influence of future economic stability on students' motivation for tertiary education. Furthermore, the finding of this study confirms that family influence is also a significant predictor of students' motivation to pursue higher education. The finding is correspondent to that of Li and Qiu (2018), Loh et al. (2014), Mehboob et al. (2012), Uka (2012) and Achoui (2004) which indicated the influence of family expectation and aspiration on students' motivation of attaining higher education. There is no doubt that students' attainment of higher education would definitely make their parents proud of them, and make the parents pleased and fulfilled in life as responsible guardians who care for their wards' future and well-being.

Future economic stability proved to be the most dominant predictor of the model $\left(\mathrm{R}^{2}\right.$ $=0.67, \beta=0.62, p<0.001)$ followed by family influence $\left(\mathrm{R}^{2}=0.67, \beta=0.18, \mathrm{p}<0.001\right)$. This study suggests the need for the government and other concerned stakeholders to investigate the employability status of the graduates and bring to their awareness any opportunity that would secure their financial stability as this is the main reason of their higher education enrolment. There is also a need for the family members to continue their support and encouragement for higher education students as it has a vital influence on their academic success and achievement. 


\section{CONCLUSION}

This study reached to a conclusion that future economic stability, family influence and motivation for higher education scales are helpful in measuring IIUM students' quest for higher education enrolment. The findings of the study revealed that future economic stability and family influence are positively and significantly correlated with IIUM students' motivation to pursue higher education. The findings also revealed that future economic stability and family influence are significant predictors of IIUM students' motivation to pursue higher education. However, this study was limited to two predictors (future economic stability and family influence) only, while in terms of sample, it was limited to IIUM students. Thus, future research could investigate further on variables like social standing, scholarship opportunities, lecturer's pedagogical approach, university's reputation and other variables that may contribute to students' motivation for higher education. Future studies should also be expanded to include other higher educational institutions in Malaysia as samples, and examine whether there would be different findings compared to the existing ones. Consequently, this study contributes to the existing body of knowledge in determining the predictors of students' motivation for higher education. It also helps to inform IIUM policy makers the need for strong networking with the industry so that they can offer employment opportunities to graduating students. In addition, higher educational institutions may make use of the findings of this study to plan for a better promotion of their programmes that can attract both school-leavers and their parents. 


\section{REFERENCES}

Achoui, M. (2004). Family impact on students' motivation. Second International Conference on Administrative Sciences, King Fahd University of Petroleum and Minerals, Saudi Arabia.

Agger, C., Meece, J., \& Byun, S. (2018). The influences of family and place on rural adolescents' educational aspirations and post-secondary enrollment. Journal of Youth and Adolescence, 47(12), 2554-2568.

Ajzen, I. (1991). The theory of planned behavior. Organizational Behavior and Human Decision Processes, 50(2), 179-211.

Al-Swidi, A., Huque, S. M. R., Hafeez, M. H., \& Shariff, M. N. M. (2014). The role of subjective norms in theory of planned behavior in the context of organic food consumption. British Food Journal.

Ali, M. S., \& Jalal, H. (2018). Higher Education as a Predictor of Employment: The World of Work Perspective. Bulletin of Education and Research, 40(2), 79-90.

Benner, A. D., Boyle, A. E., \& Sadler, S. (2016). Parental involvement and adolescents' educational success: The roles of prior achievement and socioeconomic status. Journal of Youth and Adolescence, 45(6), 1053-1064.

Bronfenbrenner, U. (1979). Contexts of child rearing: Problems and prospects. American Psychologist, 34(10), 844.

Byun, S, Meece, J. L., \& Agger, C. A. (2017). Patterns of postsecondary enrollment of rural adolescents. Research in Higher Education.

Byun, Soo-yong, Irvin, M. J., \& Meece, J. L. (2012). Predictors of bachelor's degree completion among rural students at four-year institutions. The Review of Higher Education, 35(3).

Byun, Soo-yong, Irvin, M. J., \& Meece, J. L. (2015). Rural-nonrural differences in college attendance patterns. Peabody Journal of Education, 90(2), 263-279.

Edgar, S., Carr, S. E., Connaughton, J., \& Celenza, A. (2019). Student motivation to learn: is self-belief the key to transition and first year performance in an undergraduate health professions program? BMC Medical Education, 19(1), 111.

Fajčíková, A., \& Urbancová, H. (2019). Factors Influencing Students’ Motivation to Seek Higher Education-A Case Study at a State University in the Czech Republic. Sustainability, 11(17), 4699.

Field, A. (2013). Discovering statistics using IBM SPSS statistics. sage.

Fuligni, A. J., \& Pedersen, S. (2002). Family obligation and the transition to young adulthood. Developmental Psychology, 38(5), 856.

Gobena, G. A. (2018). Family Socio-Economic Status Effect on Students' Academic Achievement at College of Education and Behavioral Sciences, Haramaya University, Eastern Ethiopia. Journal of Teacher Education and Educators, 7(3), 207-222. 
Grant, C. (2017). The contribution of education to economic growth.

Harvey, L. (2000). New realities: The relationship between higher education and employment. Tertiary Education \& Management, 6(1), 3-17.

Hasbullah, N. A., Osman, A., Abdullah, S., Salahuddin, S. N., Ramlee, N. F., \& Soha, H. M. (2016). The relationship of attitude, subjective norm and website usability on consumer intention to purchase online: An evidence of Malaysian youth. Procedia Economics and Finance, 35, 493-502.

Heckman, J. J. (2011). The economics of inequality: The value of early childhood education. American Educator, 35(1), 31.

Huang, W.-T., \& Ho, H.-F. (2017). Selection Determinants in Education Major Graduates Occupations. Contemporary Issues in Education Research (CIER), 10(2), 77-86.

Ladhari, R. (2010). Developing e-service quality scales: A literature review. Journal of Retailing and Consumer Services, 17(6), 464-477.

Li, Z., \& Qiu, Z. (2018). How does family background affect children's educational achievement? Evidence from Contemporary China. The Journal of Chinese Sociology, $5(1), 13$.

Loh, C. C., Chew, C. C., Leong, W. L., Tan, T. C., \& Yan, W. Y. (2014). A study on factors influencing students "intention to pursue higher education. UTAR.

Mehboob, F., Shah, S. M. M., \& Bhutto, N. A. (2012). Factors influencing student's enrollment decisions in selection of Higher Education Institutions (HEI's). Interdisciplinary Journal of Contemporary Research in Business, 4(5), 558-568.

O’Neal, P. W. (2007). Motivation of health behavior. Nova Publishers.

Pagés, C., \& Stampini, M. (2009). No education, no good jobs? Evidence on the relationship between education and labor market segmentation. Journal of Comparative Economics, 37(3), 387-401.

Parsons, J. E., Adler, T. F., Futterman, R., Goff, S. B., Kaczala, C. M., Meece, J. L., \& Midgley, C. (1983). Expectancies, values, and academic behaviors. Achievement and Achievement Motives, 75-146.

Richard, M. R., \& Deci, E. (1985). Intrinsic Motivation and Self Determination in Human Behaviour. New York: Plenum.

Ryan, R. M., LaGuardia, J. G., \& Rawsthorne, L. J. (2005). Self-complexity and the authenticity of self-aspects: Effects on well being and resilience to stressful events. North American Journal of Psychology, 7(3).

Schunk, D. H. (2012). Learning theories an educational perspective sixth edition. Pearson.

Swerdlik, M. E., \& Cohen, R. J. (2005). Psychological testing and assessment: An introduction to tests and measurement. Boston: McGraw-Hill. 
Uka, A. (2012). Motivational factors of albanian graduate students pursuing a master degree in education.

Warrick, C. S., Daniels, B., \& Scott, C. (2010). Accounting students' perceptions on employment opportunities. Research in Higher Education Journal, 7, 1.

White, R. W. (1959). Motivation reconsidered: The concept of competence. Psychological Review, 66(5), 297.

Wolfinbarger, M., \& Gilly, M. C. (2003). eTailQ: dimensionalizing, measuring and predicting etail quality. Journal of Retailing, 79(3), 183-198.

Wright, E., \& Horta, H. (2018). Higher education participation in "high-income" universal higher education systems. Asian Education and Development Studies. 